\title{
Role of sand in the domination of hard substrata by the intertidal alga Rhodomela larix
}

\author{
Carla M. D'Antonio* \\ Dept. of Zoology, Oregon State University, Corvallis, Oregon 97331, USA
}

\begin{abstract}
Sand movement is a common feature of most coastlines, however its effects on rocky intertidal communities have only recently begun to be examined. This study provides information on the influence of sand on a common intertidal alga that has not been previously described as psammophilous or sand-loving. The red alga Rhodomela larix (Turner) C. Agardh does occur on shores not influenced by sand but was common and frequently very abundant (greater than $50 \%$ cover) at rocky sites along the northwestern coast of the USA with both coarse and fine-grained sand accumulations. Field and laboratory observations suggest that $R$. larix can survive lengthy anoxic burial and severe sand scour, in some cases better than some of its potential competitors. In addition, potentially damaging herbivores and epiphytes may be negatively affected by sand burial. Thus sandy sites may serve as refuges from competitors, herbivores and epiphytes, resulting in patterns of spatial dominance by $R$. larix.
\end{abstract}

\section{INTRODUCTION}

The role of disturbance in maintaining or influencing community structure in marine habitats has received both theoretical and empirical attention in recent years (e. g. see Levin \& Paine 1974, Sutherland 1974, 1981, Connell 1975, 1978, Sousa 1979a, b. Highsmith et al. 1980, Paine \& Levin 1981, Robles 1982). In fact, Sousa (1979a) has suggested that disturbance events, small scale and/or patchy in space and time, probably characterize most natural systems. One such system is the marine rocky intertidal. The temperate rocky intertidal zone in North America has frequently been described as a space-limited system such that in the absence of agents which remove biomass (=disturbance as defined by Grime 1977), space becomes monopolized by one or a few species (Paine 1966, Dayton 1971, 1975, Paine \& Levin 1981). In habitats with regular disturbances, a species may become numerically or functionally dominant because of its relative resistance to the disturbance agent. Examples of regular disturbances in rocky intertidal environments include log battering, wave shock and desiccation (Dayton 1971), predation (see Connell 1975 and Paine

\footnotetext{
- Present address: Dept. of Biological Sciences, University of California, Santa Barbara, California 93106, USA
}

1977 for reviews) and the turning over of boulders (Sousa $1979 \mathrm{a}, \mathrm{b}$ ). A factor which has recently begun to receive empirical attention is the influence of sand on rocky shore organisms (Daly \& Mathieson 1977, Robles 1982, Taylor \& Littler 1982, Littler et al. 1983, Stewart 1983).

Several authors have noted the decreased diversity of organisms associated with sand-influenced rocky intertidal habitats (Chapman 1946, Stephenson \& Stephenson 1972, Phinney 1977). In addition, many investigators have described species characteristically associated with sandswept habitats (Doty 1947. Mathieson 1965, Markham \& Newroth 1972, Markham 1973, Daly \& Mathieson 1977, Phinney 1977). Markham \& Newroth (1972) suggest that several of these species may be dependent upon sandy conditions for survival.

Moving sand may scour or bury intertidal substrata. Its effects as a disturbance agent include removing plant tissue, epiphytes, or invertebrates with poor attachment to the rock surface (scouring), and decreasing light, oxygen, and substratum available to organisms (burial). The depth and duration of burial or degree of water motion will be important in determining the intensity of the disturbance.

In this study I examine the influence of sand on the occupation of space by a red alga, Rhodomela larix 
(Turner) C. Agardh, in the Oregon rocky intertidal zone. $R$. larix has not previously been described as a psammophilous or sand-loving species. However, on the Oregon coast it is abundant on moderately exposed sandswept beaches (pers. obs., Abbott \& Hollenberg 1976), and sand appears potentially important as a disturbance agent in the development and persistence of $R$. larix stands. Here I look specifically at (1) the distribution of $R$. larix with respect to rocky areas subject to sand scour or burial, (2) the distribution of potential herbivores with respect to these habitats, (3) changes in the abundance of $R$. larix and associated species through time and (4) the resistance to burial of potential competitors on sand-influenced shores. In the discussion I suggest several hypotheses to explain the influence of sand on the development and maintenance of large $R$. larix patches.

\section{Description and general distribution of the plant}

Rhodomela larix is an upright red alga which sprouts erect axes from a small perennating basal holdfast. Individual axes grow to lengths of $30 \mathrm{~cm}$ or more during the late spring and summer. Maximum length is generally achieved by mid summer after which plant tissue is lost due to a variety of factors (D'Antonio 1982). Individual axes may persist for more than $1 \mathrm{yr}$ (D'Antonio 1982). Long axes are generally broken off by mid October and very few axes greater than $8 \mathrm{~cm}$ in length survive the winter. New erect axes are sprouted each spring and plants may reach a density of 350 upright axes $225 \mathrm{~cm}^{-2}$ by mid summer. Although reproductive plants can be found from April through November, evidence of recruitment, as presented in the literature, is ambiguous. Recruitment was low during the time of this study (August 1980 through June 1982). Vegetative growth and perennation appear to be important in the maintenance of space occupancy and are probably responsible for the formation of large beds of the plant (D'Antonio 1982).

Rhodomela larix occurs in high to mid and low intertidal sites from Japan to Alaska, British Columbia, the Pacific Northwestern United States, and northern and central California (Abbott \& Hollenberg 1976). Although its distribution is variable, it is generally common and frequently abundant on moderately wave-exposed horizontal benches around $0.3 \mathrm{~m}$ above mean lower low water (Abbott \& Hollenberg 1976). It is generally in low abundance or absent from intertidal areas with high urchin densities (pers. obs.) or with wave exposed vertical faces (Saito 1980, pers. obs.). The largest and most continuous patches of $R$. larix that I have observed occur on sandswept, mid to low intertidal benches on the central Oregon coast.

\section{METHODS}

Survey of intertidal habitats and herbivore densities. To describe habitats in which Rhodomela larix occurs, 26 outercoast rocky intertidal areas were surveyed between 1 August and 22 September 1982 (Fig. 1).

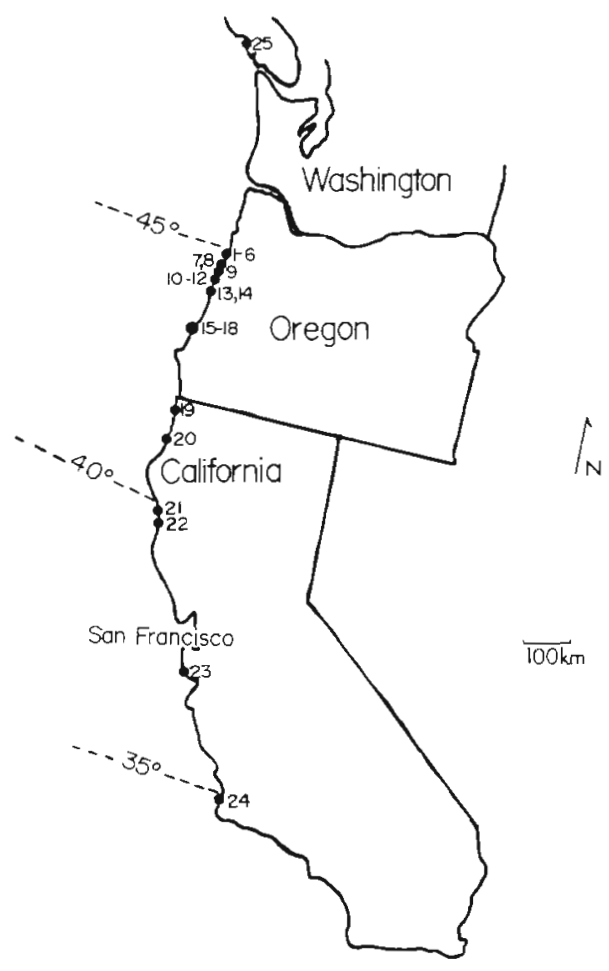

Fig. 1. Location of intertidal sites surveyed for the presence of Rhodomela larix. Numbers correspond to sites listed in Table 1

Sites were selected on the basis of accessibility during moderate low tides with ocean swells of under $1.5 \mathrm{~m}$, which unintentionally biases against exposed, vertical habitats. For all sites the following factors were noted: (1) presence and texture of sand, (2) organisms characteristic of sandy environments, (3) steepness of the rock surfaces, and (4) wave exposure conditions. The latter characteristic was difficult to evaluate for sites visited infrequently without using the plant and animal communities themselves as indicators and was therefore only qualitatively evaluated. Herbivore densities were sampled in contiguous $0.25 \mathrm{~m}^{2}$ quadrats along horizontal transects in 15 of the locations with $R$. larix. Transect length varied from 18 to $30 \mathrm{~m}$ depending on the topography of the area sampled. All herbivores (excluding small snails and amphipods) were counted and mean densities calculated for each site. The abundance of $R$. larix was estimated by counting the number of $10 \times 10 \mathrm{~cm}$ subunits in which the species occurred within each $0.25 \mathrm{~m}^{2}$ quadrat, converting this 
to a percentage, and taking a mean and standard deviation for each transect line.

Changes in the Rhodomela larix communities over time. To examine the ability of $R$. larix to persist under different sand-related disturbance regimes, beds of the plant were examined at 2 study sites, Strawberry Hill and Boiler Bay, along the central Oregon coast. R. larix is a major component of the rocky intertidal community at both sites although the presence and abundance of other plants and animals varies between the sites. In addition sand texture and movement is different at the 2 sites. Sand grain size was determined with a U.S. standard sieve series and classified according to the Wentworth scale (Thurman 1975).

Strawberry Hill is an extensive intertidal region of basaltic rock $43 \mathrm{~km}$ south of Newport, Oregon. The intertidal zone is made up of irregular rock outcroppings and gently sloping rock benches (Fig. 2). On one of the largest of these benches Rhodomela larix forms an extensive monospecific stand $40 \mathrm{~m}$ in diameter. Patches of the species are present throughout most of
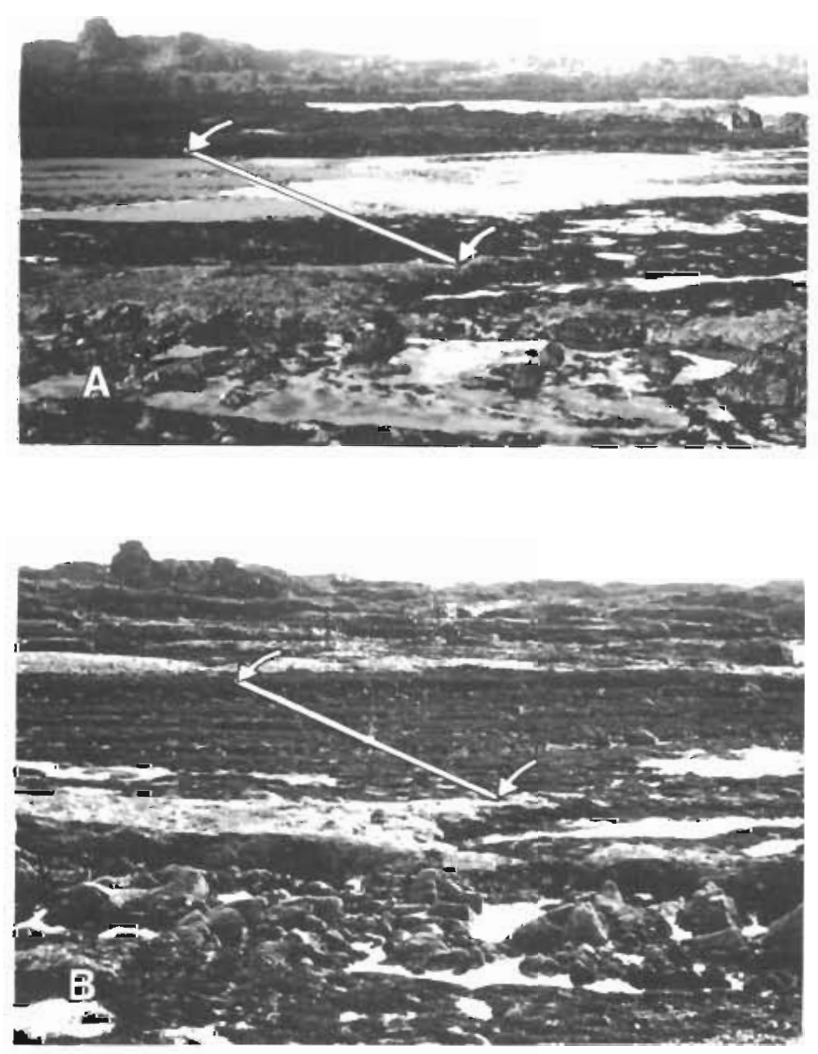

Fig. 2. Study site habitat and changes in sand cover at Strawberry Hill, Oregon. Arrows and line indicate region along which the permanent quadrats are located. (A) September 1981; (B) February 1982 the exposed rocky habitat at this site between 0.3 and $1.0 \mathrm{~m}$ above mean low water. The entire area is subject to moderate to heavy wave action although the main $R$. larix bed is protected from direct surf by a series of low horizontal basaltic dikes. It is also subjected to seasonal sand cycles such as those described by Komar (1976). Sand accumulates as wave steepness declines in the spring, with major burials occuring in the late summer. Sand is then moved seaward by wave action during fall storms.

The second site is located $24 \mathrm{~km}$ north of Newport, Oregon on the western end of Boiler Bay, Oregon (lat. $44^{\circ} \mathrm{N}$ ). The site consists of a horizontal mudstone bench between 0 and $0.7 \mathrm{~m}$ above MLW. Rhodomela larix occurs in patches on the horizontal surfaces in the surge channels and intermixed with Phyllospadix scouleri (Hooker) on the mudstone bench. The area does not appear to experience the dramatic sand cycles apparent at Strawberry Hill, although coarse sand is present throughout most of the year.

To observe community changes over time, 2 permanent transects were established at the Strawberry Hill site. The transects ran parallel to the shore and were censused seasonally between July 1981 and April 1982 and intermittently thereafter. The first of these transects was placed directly northwest of the main Rhodomela larix bed through an area of diverse algal cover. The diversity and abundance of algae were sampled along the transect line by recording the secondary (canopy) and primary (rock) cover of organisms at $30 \mathrm{~cm}$ intervals for $75 \mathrm{~m}$. Standard deviations could not be determined using this sampling scheme. The other transect line extended for $18 \mathrm{~m}$ across the main $R$. larix bed and was established to monitor changes within the $R$. larix stands themselves. Here, percent cover was monitored by recording the identity of the species in both the primary and the secondary space underneath each of 100 randomly placed dots in permanent $900 \mathrm{~cm}^{2}$ quadrats at $3 \mathrm{~m}$ intervals along the transect line. I sampled herbivore densities in three 25 $\mathrm{cm}^{2}$ quadrats within each larger quadrat. During periods of sand coverage, holes were dug at estimated $3 \mathrm{~m}$ intervals, sand depth measured and the presence and condition of the plants beneath the sand noted.

At Boiler Bay, 8 permanent quadrats of $900 \mathrm{~cm}^{2}$ were established in the main bed of Rhodomela larix in April 1981 to follow seasonal changes in the community. The percent cover of all species and primary cover of sand and rock was monitored monthly for 16 mo and intermittently for 2 yr thereafter, using a vinyl sampling quadrat with 100 randomly placed dots. In addition the growth rate of erect portions of thalli buried by sand was compared with that of axes which did not experience burial at this site. Monthly observations of growth rates were made on marked individual $R$. larix 
axes in patches near the edges of the main bed. Axes were marked by placing small plastic tags around the base of the main axis. To distinguish individual sprigs, 4 colors of tags were used in varying orders. The presence of sand on or around the base of the plants, and the presence and size of each marked axis were noted at irregular intervals between December 1980 and March 1982. The survival of entire patches of $R$. larix was monitored by carefully mapping individual patches along the edges of the main bed and noting duration of sand coverage.

Laboratory studies on sand tolerance by intertidal algae. To test the ability of Rhodomela larix to survive lengthy sand inundation and to observe changes in the plant during sand coverage, 2 sets of laboratory experiments were performed. In the first experiment 4 rocks containing 20 to 30 erect axes were examined and the presence of epiphytes noted. Eight axes on each rock

Table 1. Location and description of intertidal areas surveyed for Rhodomela larix. Tidal height estimated by tide tables, and values indicate either area surveyed, or if $R$. larix present, then the zone of occurrence

\begin{tabular}{|c|c|c|c|c|c|}
\hline Location & Exposure & $\begin{array}{l}\text { Seasons } \\
\text { visited }\end{array}$ & Sediment & R. larix & $\begin{array}{l}\text { Tidal height } \\
\text { (m) }\end{array}$ \\
\hline \multicolumn{6}{|l|}{ LINCOLN CO., OREGON } \\
\hline 1. Boiler Bay, NE & VE & All & Abs & Abs & $0-1.6$ \\
\hline 2. Boiler Bay, NE & $P$ & All & C & + & $0.7-1.0$ \\
\hline 3. Boiler Bay, central & $E$ & All & $S p-S$ & Abs & $0-1.0$ \\
\hline 4. Boiler Bay, central & $\mathrm{ME}$ & All & Abs & + & 1.0 \\
\hline 5. Boiler Bay, west end & $\mathrm{ME}$ & All & Abs & + & $1.0-1.7$ \\
\hline 6. Boiler Bay, west end & ME & All & Abs & + & $0-0.7$ \\
\hline 7. Otter Crest, north end & $E$ & $A, W$ & $C, Y$ & + & $0-1.6$ \\
\hline 8. Otter Crest, back reef & $P$ & S, W & Abs & + & 0.7 \\
\hline 9. Yaquina Head, south side & E & All & $F, Y$ & + & 1.3 \\
\hline 10. Seal Rock, north end & ME & All & Abs & + & $0.7-1.0$ \\
\hline 11. Seal Rock, central reef & ME & All & Abs & + & $0-0.7$ \\
\hline \multirow[t]{2}{*}{ 12. Seal Rock, back reef } & $\mathrm{P}$ & All & $F, Y$ & + & $1.0-1.3$ \\
\hline & \multicolumn{4}{|c|}{$\mathrm{F}, \mathrm{Y}$} & \\
\hline \multicolumn{6}{|l|}{ LANE CO., OREGON } \\
\hline 13. Strawberry Hill, surge channels & $\mathrm{ME}$ & S, W & $\mathrm{F}, \mathrm{S}$ & + & $0-1.0$ \\
\hline 14. Strawberry Hill, south benches & ME & All & $F, Y$ & + & $0-1.0$ \\
\hline \multicolumn{6}{|l|}{ COOS CO., OREGON } \\
\hline 15. Cape Arago, north Cove & E & $\mathrm{Sp}, \mathrm{S}$ & Abs & Abs & $0.3-1.0$ \\
\hline 16. Cape Arago, Simpson's Reef & $M E-P$ & S & C & + & $0.7-1.0$ \\
\hline 17. Cape Arago, S. Sunset Bay & ME & $\mathrm{S}, \mathrm{W}$ & $F_{1} Y$ & + & $0-0.7$ \\
\hline 18. Cape Arago, Squaw Island & ME & S, W & C, W & + & $0-0.7$ \\
\hline \multicolumn{6}{|l|}{ DEL NORTE CO., CALIFORNIA } \\
\hline $19.5 \mathrm{~km} \mathrm{~S}$. Crescent City & $\mathrm{ME}$ & $\mathrm{S}$ & $\mathrm{F}$ & + & $0.7-1.0$ \\
\hline \multicolumn{6}{|l|}{ HUMBOLDT CO., CALIFORNIA } \\
\hline 20. Mussel Rock, nr. Trinidad & E & S & Abs & Abs & $1.3-2.0$ \\
\hline \multicolumn{6}{|l|}{ MENDOCINO CO., CALIFORNIA } \\
\hline 21 Rockport area & ME & S & $F$ & + & 1.0 \\
\hline 22. N. Westport area & E & S & $\mathrm{C}$ & t & $0.7-1.3$ \\
\hline \multicolumn{6}{|l|}{ SANTA CRUZ CO., CALIFORNIA } \\
\hline 23. Davenport Landing & ME & $S$ & C & + & $0-0.5$ \\
\hline \multicolumn{6}{|l|}{ SANTA BARBARA CO., CALIFORNIA } \\
\hline 24. Point Sal & $\mathrm{ME}$ & S, W & $\mathrm{F}, \mathrm{S}$ & + & $0-1.3$ \\
\hline \multicolumn{6}{|l|}{ VANCOUVER ISLAND, B. C } \\
\hline 25. Kirby Point, Barclay Sound & $M E-E$ & S & Abs & Abs & $0.3-2.0$ \\
\hline 26. Execution Pt., Barclay Sound & $M E$ & $\mathrm{~S}$ & $F, S$ & + & $0.3-0.7$ \\
\hline
\end{tabular}


were individually marked and measured. All plants were placed under $15 \mathrm{~cm}$ of fine sand in a running seawater tank with aeration by 2 weighted air hoses at the sand surface. Two rocks were examined after $2 \mathrm{wk}$ and then replaced under the sand. At $6 \mathrm{wk}$ they were placed in a tank under 'grow-lux' lights without sand for continued observations on survival. After $14 \mathrm{wk}$ the remaining 2 rocks were removed from under the sand, examined and placed in the seawater tank for further observation.

The second experiment was designed to test the relative survivorship under sand of several species of algae commonly found in mid and low intertidal habitats and often interspersed with Rhodomela larix. Plants of 7 species, including $R$. larix, were collected by chipping away a portion of the rock to which they were attached. At least 7 specimens of each species were collected so that plants could be divided into 7 sets with 1 specimen of each species per set. Four sets were placed in a running seawater tank under 15 to 20 $\mathrm{cm}$ of fine sand. The remaining 3 sets were placed in a well-lit aerated seawater tank to serve as controls. After $1 \mathrm{mo}, 2$ of the experimental sets were removed from the sand and examined to determine the general condition of the plants. Controls were also examined at this time. The 2 remaining experimental sets were removed from the sand after 3 mo and monitored in the same way.

\section{RESULTS}

\section{Latitudinal distribution of Rhodomela larix}

Rhodomela larix was present at 21 of the 26 sites visited in summer 1981 (Table 1). The remaining 5 sites were very exposed sloping rocky outcroppings. Where horizontal surfaces were present at these sites, they often contained large numbers of sea urchins and/ or clumps of mussels. There was no evidence of sediment accumulation or movement at any of these waveexposed sites.

Sixteen of the 21 sites where Rhodomela larix was present showed evidence of sediment accumulation or seasonal sand cycles (e. g. Sites 2, 6, 8 and 11 to 14). The community of plants and animals at these sites (Table 2) was also characteristic of that described for sand-influenced rocky shores (Abbott \& Hollenberg 1976, Phinney 1977, Taylor \& Littler 1982). The remaining 5 sites (with $R$. larix, but no sand), were more exposed to wave action and where $R$. larix occurred it was generally 0.3 to $0.6 \mathrm{~m}$ higher above MLW than at most of the other 15 sites. Thus $R$. larix does occur without sand, but was present at all sites with sand accumulations.

\section{Herbivore densities}

The highest densities of herbivores, that graze algae at the rock surface, occurred at sites without sediment accumulations (Table 3).No large herbivores were observed at the sites with the greatest sand accumulations. During an intensive search of the Strawberry Hill, Seal Rock, and Otter Crest areas where sand coverage of the substrate was high, I found the chiton Katharina tunicata only on elevated benches or vertical walls that were never observed to be covered by sand. An occasional individual of the chiton species Mopalia muscosa was seen on horizontal surfaces in

Table 2. Sessile organisms commonly found with Rhodomela larix on emergent substrates. List was compiled from observations at 21 intertidal areas in Oregon and California where $R$. larix was present. Longevity data from Abbott \& Hollenberg 1976

\begin{tabular}{|c|c|c|}
\hline Species & $\begin{array}{l}\text { Longe- } \\
\text { vity }\end{array}$ & $\begin{array}{l}\text { Season } \\
\text { when most } \\
\text { abundant }\end{array}$ \\
\hline \multicolumn{3}{|l|}{ Chlorophyta } \\
\hline Ulva sp. & $\mathrm{A}^{*}$ & $S$ \\
\hline Cladophora columbiana & $P$ & $\mathrm{~S}$ \\
\hline \multicolumn{3}{|l|}{ Phaeophyta } \\
\hline Leathesia spp. & A & $S$ \\
\hline Hedophyllum sessile & $\mathrm{P}$ & $\mathrm{S}$ \\
\hline Egregia menziesii & $\mathrm{P}$ & $\mathrm{S}$ \\
\hline Fucus distichus & $P$ & $\mathrm{~L}$ \\
\hline Phaeostrophion irregulare & $\mathrm{P}$ & W \\
\hline \multicolumn{3}{|l|}{ Rhodophyta } \\
\hline Cryptosiphonia woodii & $\mathrm{P}$ & $\mathrm{S}$ \\
\hline Corallina vancouveriensis & $\mathrm{P}$ & $\mathrm{L}$ \\
\hline Bossiella plumosa & $\mathrm{P}$ & $\mathrm{L}$ \\
\hline Plocamium sp. & $P$ & W \\
\hline Iridaea cordata & $\mathrm{P}$ & $S$ \\
\hline I. heterocarpa & $\mathrm{P}$ & $\mathrm{S}$ \\
\hline Halosaccion glandiforme & $\mathrm{P}$ & $\mathrm{S}$ \\
\hline Gigartina papillata & $\mathrm{P}$ & S \\
\hline Microcladia borealis & $\mathrm{P}$ & $\mathrm{S}$ \\
\hline Odonthalia floccosa & $\mathrm{P}$ & $\mathrm{S}$ \\
\hline Gymnogongrus linearis & $P$ & $\mathrm{~L}$ \\
\hline Ahnfeltia plicata & $P$ & W \\
\hline \multicolumn{3}{|l|}{ Angiospermae } \\
\hline Phyllospadix scouleri & $\mathrm{P}$ & $\mathrm{L}$ \\
\hline P. torreyi & $P$ & $\mathrm{~L}$ \\
\hline \multicolumn{3}{|l|}{ Cnidaria-Anthozoa } \\
\hline Anthopleura elegantissima & $P$ & U \\
\hline \multicolumn{3}{|l|}{ Mollusca-Bivalvia } \\
\hline Mytilus californianus & $\mathrm{P}$ & $\mathrm{L}$ \\
\hline M. edulis & $\mathrm{P}$ & Spring \\
\hline \multicolumn{3}{|c|}{$\begin{array}{l}\text { Abbreviations: } \mathrm{A}=\text { annual, } \mathrm{P}=\text { perennial; } \mathrm{S}=\text { summer, } \\
\mathrm{W}=\text { winter, } \mathrm{L}=\text { little seasonal variation observed, } \mathrm{U}= \\
\text { unknown } \\
\text { - Known to have some perennial cells }\end{array}$} \\
\hline
\end{tabular}


sandy areas. This species appears to be able to tolerate sand burial (pers. obs., Littler et al. 1983) but was rare at all sites I examined. Urchins Strongylocentrotus purpuratus were absent from all sandy benches although common at more exposed areas with Rhodomela larix. Sites with coarse grained sand or small amounts of the finer grained sand had an occasional chiton and sometimes high densities of the herbivorous gastropod Tegula funebralis but otherwise lacked large herbivores (Table 3). In many of these areas chiton and urchin abundance appears to vary little seasonally (pers. obs., T. Turner pers. comm.).

Chiton density was inversely correlated with Rhodomela larix abundance $\left(\mathrm{r}^{2}=0.43, \mathrm{~b}=1.61\right)$ at the sites sampled. Those sites with higher chiton densities had large amounts of bare space and were frequently dominated by the kelp Hedophyllum sessile with an understory of erect coralline algae (Bossiella plumosa and Corallina vancouveriensis). Such results suggest that either (1) chitons negatively affect $R$. larix $x_{i}(2)$ sand has a negative effect on chitons but not on $R$. larix (3) both (1) and (2), or (4) chitons may not establish in areas dominated by $R$. larix.

\section{Survival of Rhodomela larix after sand burial in the field}

The percent cover of Rhodomela larix on the permanent transect lines and permanent quadrats at Strawberry Hill and Boiler Bay changed little over time (Table 4, Fig. 3 \& 4). Percent cover of $R$. larix on

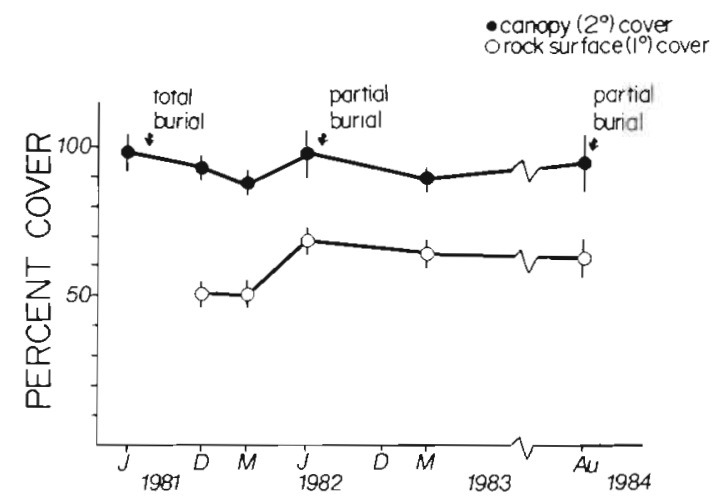

Fig. 3. Percent cover of Rhodomela larix in quadrats within the main $R$. larix bed (Transect 1), Strawberry Hill, Oregon. Bars represent standard deviations

Table 3. Herbivore density transects in sites containing Rhodomela larix. Estimation procedures for $R$. larix abundance are described in the text, standard deviations are in parentheses. Quadrat size $=0.25 \mathrm{~m}^{2}$. "Sites with most extreme sand level fluctuations. 'Chiton density' includes both Katharina tunicata and Mopalia muscosa. For 'Misc. herbivores', numbers represent number of quadrats in which the particular herbivore was present

\begin{tabular}{|c|c|c|c|c|c|c|}
\hline Site \& description & $\begin{array}{l}\text { Tidal } \\
\text { height } \\
\text { (m) }\end{array}$ & $\begin{array}{l}\text { Sedi- } \\
\text { ment }\end{array}$ & $\mathrm{n}$ & $\begin{array}{c}R \text { larix } \\
\text { abundance }\end{array}$ & $\begin{array}{c}\text { Chiton density } \\
\mathrm{qt}^{-1}\end{array}$ & $\begin{array}{c}\text { Misc. } \\
\text { herbivores }\end{array}$ \\
\hline \multicolumn{7}{|l|}{ LINCOLN CO., OREGON } \\
\hline Boiler Bay, sloping shelf, exp. & 1.0 & Abs & 21 & $0.72(2.31)$ & $3.57(2.18)$ & - \\
\hline Boiler Bay, flat bench, prot. & 0.5 & $\mathrm{C}, \mathrm{Y}$ & 28 & $31.65(26.84)$ & 0 & 3 T.f. $1 \mathrm{qt}$ \\
\hline Boiler Bay, central, mod exp. & 1.0 & Abs & 41 & $17.49(24.20)$ & $1.34(1.28)$ & S.p. $2 \mathrm{qt}^{\mathrm{t}}$ \\
\hline Otter Crest, exp. shelf & 1.3 & Abs & 38 & $17.0(20.8)$ & $0.83(1.17)$ & small limp. abund. \\
\hline Otter Crest, mod. exp. ridge & 0.5 & Abs & 29 & $8.8(12.8)$ & $0.78(1.17)$ & S.p. $6.52 \mathrm{qt}^{-1}$ \\
\hline " Otter Crest, back reef & 0.7 & $F, Y, S$ & 32 & $18.0 \quad(14.7)$ & 0 & T.f. $2 \mathrm{qt}$ \\
\hline Sral Rock, mod exp. ridge & 1.0 & Abs & 29 & $11.20(14.00)$ & $0.61(0.91)$ & large C.p. $5 \mathrm{qt}$ \\
\hline Seal Rock, mod. exp. central reef & 1.0 & $F, S$ & 48 & $26.35(23.33)$ & $0.17(0.52)$ & - \\
\hline - Seal Rock, prot. back reef & 1.0 & $F, Y, S$ & 37 & $33.33(21.16)$ & & - \\
\hline \multicolumn{7}{|l|}{ LANE CO., OREGON } \\
\hline - Strawberry Hill, mod exp horiz. shelf & 0.5 & $F, S$ & 36 & $45.0(2.84)$ & 0 & - \\
\hline Hill, mod exp. below main bed & 0.3 & $F, S$ & 72 & 27.0 & 0 & - \\
\hline \multicolumn{7}{|l|}{ COOS CO., OREGON } \\
\hline Cape Arago, Sunset Bay, mod. exp. & 0.6 & C. W & 19 & $61.0(5.7)$ & 0 & T.f. $5.22 \mathrm{qt}^{-1}$ \\
\hline C. Arago mod exp horiz. shelf & 0.6 & $F, Y$ & 10 & $31.67(15.70)$ & 0 & occas. Tf. \\
\hline
\end{tabular}


Table 4. Species composition (\% cover) and sand cover along transect northwest of main Rhodomela larix bed at Strawberry Hill. Both July sets were taken during partial sand coverage. December was after, and April before coverage

\begin{tabular}{|c|c|c|c|c|}
\hline Cover component & Jul 1981 & Dec 1981 & Apr 1982 & Jul 1982 \\
\hline Sand & 58.0 & 6.6 & 10.6 & 27.0 \\
\hline Rhodomela larix & 22.0 & 27.0 & 24.0 & 25.0 \\
\hline Bossiella plumosa & 3.5 & 6.6 & 5.3 & 4.4 \\
\hline Corallina vancouveriensis & 2.8 & 5.2 & 3.0 & 0.7 \\
\hline Coralline crust & 2.1 & 14.8 & 3.0 & 0.5 \\
\hline Gymnogongrus linearis & 2.1 & 5.2 & 6.0 & 6.0 \\
\hline Phyllospadix 2 spp. rhizomes & 2.1 & 9.6 & 3.0 & 7.4 \\
\hline Iridea cordata & 1.4 & 3.0 & 3.8 & 4.4 \\
\hline Ptilota filicina & 1.4 & 1.5 & 1.5 & 3.0 \\
\hline Microcladia borealis & 1.4 & 0 & 0 & 0 \\
\hline Plocamium sp. & 0.7 & 8.1 & 10.0 & 2.2 \\
\hline Leathesia difformis & 0.7 & 0 & 0 & 0 \\
\hline Dilsea californica & 0.7 & 0 & 0 & 0.5 \\
\hline Cryptosiphonia woodii & 0.7 & 0 & 0 & 0 \\
\hline Ulva sp. & 0.7 & 0 & 0.7 & 1.5 \\
\hline Ahnfeltia plicata & 0 & 1.5 & 1.5 & 0 \\
\hline Phaeostrophion irregulare & 0 & 0.5 & 3.8 & 0 \\
\hline Codium setchellj & 0.5 & 1.5 & 4.5 & 1.5 \\
\hline Bare space & 0 & 0 & 1.5 & 0 \\
\hline Polysiphonia sp. & 0 & 0 & 0.7 & 0 \\
\hline Porphyra sp. & 0 & 0 & 0 & 0.5 \\
\hline Anthopleura elegantissima & 0 & 0 & 0 & 2.2 \\
\hline
\end{tabular}

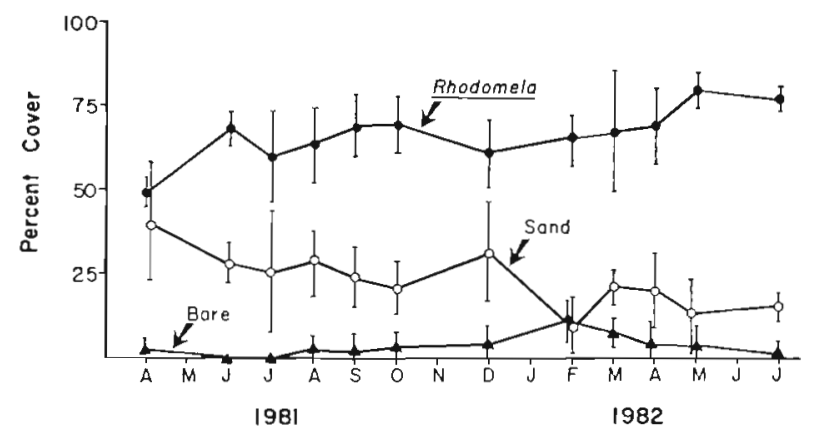

Fig. 4. Percent cover of the primary (i.e. rock) surface in permanent quadrats at Boiler Bay, Oregon. Bars represent standard deviations

primary space declined at both sites during the winter. However, it was still abundant in all areas throughout the year, and after 4 yr of observation.

Sand profile changed dramatically with season at Strawberry Hill (e. g. see Fig. 2). When the study site was first visited (Feb 1981), very little sand was observed around the base of Rhodomela larix plants and no deposits of sand were apparent in the study area. By late July 1981, 2.5 to $7.5 \mathrm{~cm}$ of sand had accumulated around the holdfasts of the $R$. larix in the main bed and intrusions of sand were common along both transect lines. By mid August, 30 to $60 \mathrm{~cm}$ of densely packed, fine-grained $(1 / 8$ to $1 / 4 \mathrm{~mm})$ sand covered most of the main bed. Sand began to disappear from the area during early to mid November; by late November very little sand was present at the base of the $R$. larix plants. Sand withdrawal continued throughout the winter and depositon was not observed again until summer 1982. In 1982-1983 a similar pattern of sand accumulation and disappearance occurred although sand burial in the main bed did not exced 30 $\mathrm{cm}$ and was thus considered partial burial (Fig. 3). Observations in December 1982 and March 1983 showed that sand was absent from the area. Recent observations in summer 1984 again showed sand accumulation to be occurring.

Little damage was evident on Rhodomela larix removed from beneath $40 \mathrm{~cm}$ of sand at Strawberry Hill within $2 \mathrm{wk}$ of the major burial in August 1981 and dense populations of diatoms and amphipods, on $R$. larix in July, were absent. A large percentage of plants removed from under the sand had mature tetrasporangia on their axes. I saw no evidence of decay. However, $R$. larix examined in mid September (more than 1 mo after burial) appeared to be experiencing anoxic conditions. The sand at the depths to which it was buried was blackened and the odor was typical of that produced by anoxic sediment layers. Although the upper portions of the plants disintegrated when touched, the lower 5 to $7 \mathrm{~cm}$ appeared healthy.

Sand apparently did not alter the percent cover of Rhodomela larix on primary space along either transect line, however the appearance of the plants did 
change after sand coverage. Changes observed were: (1) few of the diatom epiphytes and virtually none of the macro-algal epiphytes associated with $R$. larix (such as Leathesia nana, Halosaccion glandiforme and Ulva sp.) persisted throughout the burial period, although they remained at nearby unburied areas; (2) virtually all of the reproductive portions of $R$. Iarix thalli decayed during the period of burial; (3) the mean size of a $R$. larix axis was much smaller after burial (before : $34 \mathrm{~cm}, \mathrm{SD}=46.2 \mathrm{~cm}, \mathrm{n}=27$, after: $6.6 \mathrm{~cm}, \mathrm{SD}$ $=3.00, \mathrm{n}=25$ ); and (4) $R$. larix axis density was reduced, that is the percent cover of $R$. larix in the primary space declined after burial. In February of 1982 the plants in the region where sand burial had been the deepest looked healthy and appeared to have new growth along the tips of their main axes.

Effect of sand coverage on other plants in the area was variable. Some species appeared unchanged. For example, near the main bed, patches of Phyllospadix sp. and Gymnogongrus linearis appeared similar before and after sand burial. On the transect line below the main bed, the percent cover of several species was not negatively affected by sand cover (Table 4). The increase in percent cover of many of these species between July and December 1981 (e. g. Rhodomela larix, Bossiella plumosa, Corallina vancouveriensis,. Gymnogongrus linearis and Plocmium sp.) to a large extent reflects the disappearance of sand already covering patches of these algae in July. Other species, specifically the perennial red algae Microcladia borealis, Dilsea california and Cryptosiphonia woodii disappeared after sand coverage (Table 4).

Sand also appears to affect some of the large invertebrates present at Strawberry Hill. For example, the starfish Pisaster ochraceus is abundant there, and during the period of sand coverage a large number of starfish were found dead on the sandy substrata. Most of these appeared to have had their ampullae eaten by gulls and the presence of sand may have hindered the ability of the starfish to cling to the rocks. Sand also appears to affect chiton density. Experiments not previously described, where chitons were transplanted into bare patches within Rhodomela larix beds in the early summer before sand inundation began, demonstrated that chitons survive better at Strawberry Hill on rocky outcroppings that do not experience sand burial.

Sand movement at Boiler Bay differed from the pattern at Strawberry Hill. Rather than large scale movements of fine-grained sand, a 5 to $15 \mathrm{~cm}$ layer of very coarse (1 to $2 \mathrm{~mm}$ ) sand moved back and forth across the Rhodomela larix bed between December 1980 and March 1981 and again between November 1981 and March 1982. Portions of the bed were intermittently covered with sand and all marked plants outside of the main bed were under 7.6 to $13 \mathrm{~cm}$ of sand between
January and March 1981. No indication of anoxia was ever observed beneath the sand. After the sand receded, 13 out of 14 marked sprigs remained in the region of total coverage. Within the main bed where sand coverage was never complete, 20 out of 32 marked axes survived during the same time period.

A similar pattern of sand movement at Boiler Bay occurred in winter 1982 and patches of bare rock appeared within the Rhodomela larix beds. A slight increase in the percentage of bare rock was also observed in permanent quadrats during this time (Fig. 4). Many patches of $R$. larix in the surge channel area contained erect axes only 1 to $3 \mathrm{~cm}$ tall, which were barely visible above the layer of coarse sand. An examination of these axes under a dissecting scope revealed gouges full of sand grains in the plant tissue. $R$. larix thalli in nearby unscoured areas appeared healthier and showed fewer signs of scour damage.

A small summer pattern of sand movement did occur at the Boiler Bay site. Again, however, the sand was of a coarse rather than fine nature and sand depth never exceded $5 \mathrm{~cm}$. Many marked axes became covered with sand in late July and early August. When sand levels receded in October, 9 out of 9 marked axes were present. It was not possible to compare axis losses from areas without sand cover during this same time interval because such areas were at different tidal heights or had a large cover of epiphytes. A similar pattern of sand movement occurred in summer 1982. Nails fixed into the rock indicated that sediment accumulations of up to $7 \mathrm{~cm}$ occurred in the main Rhodomela larix bed at that time.

\section{Laboratory experiments of sand tolerance}

\section{Experiment 1: Survival of Rhodomela larix}

In the laboratory Rhodomela larix also tolerated sand burial. All 16 of the markers were present on the plants examined after $2 \mathrm{wk}$ of burial but no marked axes increased in length. Diatom (both sets of erect axes) and Leathesia nana (one set) epiphytes were still present although the latter disintegrated when handled and emanated a rotten odor. The cover of diatoms was not quantified but appeared much reduced. After $6 \mathrm{wk}$ the same plants were re-examined and 13 out of 16 marked axes were still intact. The plants had not grown and both diatom and $L$. nana epiphytes were absent. After $14 \mathrm{wk}$ of burial all axes greater than $2 \mathrm{~cm}$ of 2 of the plants had become detached and/or had suffered marked disintegration. None of the remaining axes had diatom epiphytes as they had at the outset of the experiment. Two blades of the red alga Iridaea cordata growing adjacent to one of the plants were 
absent when the $R$. larix was uncovered. All plants subsequently survived the winter in the laboratory tanks without sand, although no new growth was apparent.

Experiment 2: Survival of Rhodomela larix and other algae

Rhodomela larix is more tolerant of sand burial than the other species tested (Table 5). After 1 mo, all 4 of the upright algae other than $R$. larix showed declines in the amount of plant tissue present although at least some portion of most specimens remained. Controls at this time were similar in appearance to their initial condition.

Examination of the plants buried for 3 mo revealed an even more striking difference between Rhodomela larix and other species. R. larix and Ulva lactuca were the only specimens of upright macroalgae that retained any visible tissue. Both of the rocks with $U$. lactuca retained only small $<5 \mathrm{~mm}$ tufts of the blades. On the other hand, although both the $R$. larix and the coralline crusts were reduced in size and slightly discolored they were similar in morphology to their initial state. However, it should be noted that I could not determine at that stage if they were in fact alive. After 3 mo in a running seawater tank without sand the $R$. larix had regained its original dark red color. Although these experiments could not mimic field conditions because of the lack of wave action, conditions in the laboratory may have been harsher than those in the field because anoxia may have been greater. Therefore, my results support the contention that $R$. larix is better adapted to withstand dark and anaerobic conditions that the other species of algae listed in Table 5. Future field experiments could elucidate the importance of this finding under more natural conditions.

\section{DISCUSSION}

\section{Role of sand in community structure}

The common occurrence and frequent abundance of Rhodomela larix on sandswept intertidal benches (Table 1) suggests that sand may be linked with the development and persistence of $R$. larix beds. Since $R$. larix also occurs in areas where sand accumulations do not occur, individuals are not directly dependent upon the presence of sand for survival. However, the indirect benefits of sand may create the patterns of abundance of $R$. larix observed at these sites. Several mechanisms, none of which are mutually exclusive, may be operating to maintain large monospecific stands of $R$. larix: (1) sandy areas may serve as refuges for $R$. larix from the potentially detrimental effects of large herbivores such as chitons and sea urchins; (2) seasonal sand coverage may eliminate many of the smaller herbivores such as amphipods, and the small gastropod Lacuna marmorata, which are able to colonize and consume the plant (D'Antonio 1985); (3) sand coverage may eliminate detrimental epiphytes while protecting the lower portions of $R$. larix from exposure stress during the summer months; (4) sand may eliminate at least some potential competitors which cannot withstand anoxic burial or sand scour; (5) sand coverage may limit algal recruitment, giving an advantage to those species which perennate and grow vegetatively; (6) once established, R. larix beds may be resistant to the effects of grazers and/or sand disturbance.

The 2 major large herbivores absent from sandy sites, the chiton Katharina tunicata and the urchin Strongylocentrotus purpuratus (Table 3 ) have been shown elsewhere to have important effects on algal populations (Paine \& Vadas 1969, Dayton 1975, Paine 1977, Sousa et al. 1981, Gaines 1985). For example, in

Table 5. Algal tissue changes after periods of sand coverage in the laboratory

\begin{tabular}{|c|c|c|c|c|}
\hline \multirow[t]{2}{*}{ Species } & \multicolumn{2}{|c|}{$1 \mathrm{mo}$} & \multicolumn{2}{|l|}{$3 \mathrm{mo}$} \\
\hline & Control & Experimental & Control & Experimental \\
\hline Rhodomela larix & No change & No change & Little change & $\begin{array}{l}\text { Upright portions decay- } \\
\text { ing, sl. discolored, hold- } \\
\text { fast and crust intact }\end{array}$ \\
\hline Microcladia borealis & No change & No trace & Holdfast remains & No trace \\
\hline Cryptosiphonia woodii & Little change & Basal $<1 \mathrm{~cm}$ remains & Basal $1-2 \mathrm{~cm}$ remain & No trace \\
\hline Ulva sp. & Little change & $\begin{array}{l}1 \text { plant gone, } 2 \text { nd plant } \\
\geq 1 / 2 \text { initial size }\end{array}$ & $\begin{array}{l}\text { Present, blades } 1 / 2 \text { ini- } \\
\text { tial }\end{array}$ & $\begin{array}{l}\text { Basal tufts on both } \\
\text { rocks }(90 \% \text { lost), discol- } \\
\text { ored }\end{array}$ \\
\hline Gigartina papillata & Little change & $\begin{array}{l}\text { Blade present, no } \\
\text { papillae }\end{array}$ & Present, no papillae & No trace \\
\hline Coralline crust & No change & No change & No change & Red-orange in color \\
\hline
\end{tabular}


the Pacific Northwest rocky intertidal, dense populations of urchins occur in many areas and produce a community dominated by either crustose coralline algae and ephemeral green and red algae (Paine \& Vadas 1969), or coralline algae and grazer resistant plants such as Phyllospadix spp. (Paine 1977). In the absence of urchins, large brown algae and perennial reds predominate (Dayton 1975, Paine \& Vadas 1969). Also, in 2 southern California intertidal areas, removal of urchins resulted in rapid recruitment of upright algae and eventual domination of plots by perennial red algal turfs (Sousa et al. 1981).

The precise effect of urchins on Rhodomela larix has not been well documented. Although I have observed Strongylocentrotus purpuratus eating $R$. larix in the laboratory, they do not usually directly co-occur in the same microhabitats. In Oregon, microhabitats with high densities of urchins tend to be devoid of fleshy macrophytes (Gaines 1985, own pers. obs.). R. larix is largely confined to horizontal emergent substrata in these areas, while urchins occur primarily in tide pools, shallow channels and crevices where fine sand is absent.

The lack of large chitons in sandswept areas and the low abundance of Rhodomela larix in high chiton density areas (Table 3 ) suggests that the survival and growth of $R$. larix is enhanced by the absence of this molluscan grazing pressure. Observations presented by Paine (1984) further support the suggestion that on Pacific Northwest shores $R$. larix is absent where chiton densities are high $\left(>20 \mathrm{~m}^{-2}\right)$. A preliminary experiment using field enclosures of Katharina tunicata suggests that these molluscs are able to eat adult $R$. larix plants. Chitons were placed in pens containing a mixture of fleshy macrophytes including primarily $R$. larix and Cryptosiphonia woodii. With a density of less than $12 \mathrm{~m}^{-2}$ these chitons significantly reduced the percentage cover of $R$. larix, relative to the controls, in the quadrat where they were introduced in 6 wk (Table 6). Dethier (1982) has also observed $K$.

Table 6. Influence of the grazing chiton Katharina tunicata on the percent cover of Rhodomela larix in fenced enclosures over 2 mo. Percent cover values were obtained by computerdigitalized calculations of area from photographs of the quadrats

\begin{tabular}{|ccc|}
\hline & Density $\mathrm{m}^{-2}$ & $\begin{array}{c}\text { \% change of } \\
\text { R. larix }\end{array}$ \\
\hline Chitons present & & \\
Replicate 1 & 12 & -25.44 \\
2 & 8 & -8.13 \\
Chitons absent & & \\
Replicate 1 & 0 & +2.50 \\
2 & 0 & -0.70 \\
\hline
\end{tabular}

tunicata eating $R$. larix in pools in the San Juan Islands. Chitons may also (1) eliminate algal sporelings preventing $R$. larix recruitment (Dayton 1975), and (2) keep dense clumps of pre-existing plants from spreading vegetatively. Gaines (pers. comm.) observed a noticeable increase in the percent cover of $R$. larix on intertidal benches following the removal of $K$. tunicata. Thus the absence of chitons in sandy areas may increase the likelihood of growth and recruitment of $R$. larix. In addition, once $R$. larix turfs are well established they may be avoided by chitons.

The precise role of sand in causing the decreased chiton and urchin densities observed at the sandy sites is unclear. The transplant experiments examining the effect of sand burial on adult chiton survivorship indicate that the mantle of Katharina tunicata suffers severs abrasion during $1 \mathrm{wk}$ of sand coverage. These chitons did not appear to be able to tolerate burial because they disappeared from the buried area during sand coverage, while many of the transplanted chitons in unburied areas survived (Fig. 5). Sand may also

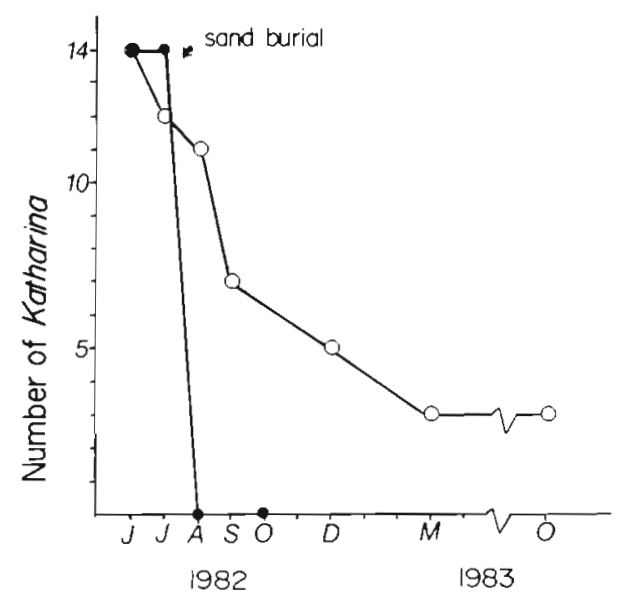

Fig. 5. Survival of individuals of Katharina tunicata after transplantation. Open circles represent chitons transplanted to areas which did not experience sand coverage. Closed circles represent chitons transplanted to areas which experienced sand coverage

have a negative effect on the larval or juvenile phases of these herbivores, and recruitment may simply not occur in these habitats.

Small herbivores, such as the prosobranch gastropod Lacuna marmorata, the isopod Idotea wosnosenskii, and an array of gammarid amphipod species colonize Rhodomela larix and are able to consume it ( $\mathrm{D}^{\prime}$ Antonio 1985). The small crustaceans and gastropods begin to increase in density in the $R$. larix fronds in mid to late summer (D'Antonio 1982, unpubl.). In areas where sand coverage was never complete, these animals were present throughout the fall and into the winter. 
Sand burial at Strawberry Hill eliminated all crustaceans and small gastropods from the affected patches of $R$. larix, thus decreasing their possible detrimental effects on the alga.

The reduction in epiphyte cover caused by sand burial may also increase the survivorship of Rhodomela larix plants. At Boiler Bay, where sand coverage was never complete, many epiphytes persisted throughout the year. This was also apparent in 2 patches of $R$. larix at Strawberry Hill which escaped total sand burial in 1981. These patches remained covered with a dense growth of the chain-forming diatom Ishmia nervosa and grew little in the spring of 1982 (D'Antonio 1985). Some epiphytes are also correlated with an increased rate of axis breakage and often the pulling up of one $R$. larix axis resulted in the removal of several adjacent axes because of holdfast connections. Thus the removal or decay of epiphytes due to sand may decrease the loss of clumps of axes during fall and winter storms.

The ability of Rhodomela larix to withstand prolonged sand coverage better than many other algal species is likely to be important although not essential to the development and maintenance of $R$. larix stands. Several algal species that did not survive in laboratory sand burial are common in low intertidal habitats where sand is not abundant. In addition, they are sometimes found as epiphytes on R. larix (D'Antonio 1985), particularly in areas where bare space is uncommon (pers. obs.). The elimination of these potential space occupiers and potential epiphytes by sand may increase the likelihood of dominance by $R$. larix.

The elimination of potential space competitors cannot be the whole explanation for Rhodomela larix monocultures because several other species can tolerate sand. These include Ahnfeltia plicata, Gymnogongrus linearis, Phaeostrophion irregulare, Egregia menziesii, Laminaria sinclairii, and Hedophyllum sessile. The latter species has been described as a functional dominant in moderately exposed rocky intertidal communities on the coast of Washington (Dayton 1975, Paine 1984). (Removal of $H$. sessile results in an increase in several algal species including $R$. larix). Once established these algae appear to inhibit the re-establishment of a $H$. sessile canopy (Dayton 1975). While $H$. sessile is predictably present, it is not dominant on the sandswept reefs where $R$. larix is abundant. Sand may limit its ability to achieve dominance, and the establishment and persistence of perennial reds such as $R$. larix in these habitats, will in turn inhibit the ability of $H$. sessile to invade.

The capacity of a plant to reproduce vegetatively may be a feature important to its persistence on sandinfluenced rocky shores. This has recently been suggested by Stewart (1963). A variety of psammophilous plants, such as Rhodomela larix, Phyllospadix scouleri, Ahnfeltia plicata, Gymnogongrus linearis and Laminaria sinclairii can grow in this manner while Egregia menziezii and Hedophyllum sessile cannot. Markham (1973) has suggested that rhizomatous growth is important to the development and persistence of large populations of $L$. sinclairii in the low zone on sandswept northern Oregon shores. Species which cannot grow vegetatively must recruit into these intertidal areas during the period of the year when sand is not present and reach a large enough size for at least the basal portions to withstand the forthcoming burial or scour. Opportunistic species such as Porphyra sp. and Ulva sp. may also proliferate in clearings during the period of the year when sand is absent

\section{Pesistence and stability in Rhodomela larix beds}

This study and subsequent observations indicate that the percent cover of Rhodomela larix stayed constant over 4 summers at both the Boiler Bay and the Strawberry Hill sites. Photographs of the Boiler Bay site indicate that these beds have been in roughly the same location for a minimum of 8 yr (T. Tumer pers. comm.). Photographs from 1960 of an additional site where $R$. larix is common on the southern Oregon coast also indicate that $R$. larix beds, once established, may persist for long periods of time (J. Pederson pers. comm.). Individual $R$. larix axes have the ability to perennate and show the ability to regenerate from a minimal number of basal cells (D'Antonio 1982). Thus the minor fluctuations and general constancy of cover in the $R$. larix beds followed in this study probably reflect conditions which have persisted for many years.

In sand-influenced rocky intertidal habitats in Oregon, Rhodomela larix may eventually be outcompeted by the surfgrass Phyllospadix scouleri (Turner 1982). However, the rate at which the surfgrass invades established beds of $R$. larix appears to be slow. I have observed settlement and germination of $P$. scouleri seeds in the $R$. larix beds at Boiler Bay, however no seedlings have become established in any of the permanent quadrats over $4 \mathrm{yr}$ of observation, and Turner (1982) has found that in general survival of seedlings is poor and vegetative growth of established $P$. scouleri individuals is slow. At Strawberry Hill I did not observe settlement of any $P$. scouleri seeds during this study, even though patches of $P$. scouleri occur adjacent to patches of $R$. larix. Seed settlement occurs in the fall on the Oregon coast (Turner 1982) and in some years may occur before the seaward movement of the intertidal sand bar at Strawberry Hill. 


\section{Geographic considerations}

Much of our knowledge of community structure in rocky intertidal habitats comes from studies in Washington state. These Washington study sites may not be characteristic of the entire northwest region of the United States. For example the studies of Connell (1970), Dayton $(1971,1975)$, Paine (see 1977 for review, 1981, 1984), and Dethier \& Duggins (1984) have focused on very wave-exposed communities at the northern tip of Washington state or the protected inland waters of the San Juan Islands. In the latter area the lowest low tides occur during months when exposure to the sun is the most extreme. Rhodomela larix is confined mainly to intertidal pools in these habitats (Muenscher 1915), and the occurrence of many plant and animal species on emergent substrata is lower in the intertidal than on the outer coast (Dethier pers. comm.). In addition, the Oregon coast may be more strongly influenced by sand because of the greater number of rivers there, and sediments from the Columbia river which are transported south in surface waters (Runge 1966, Hartlett 1972). Thus the composition of communities in rocky intertidal habitats may reflect this influence. Phinney (1977) presents a review of algal species found in Oregon and suggests that the lower algal diversity in this region, and the discontinuous distribution of many species found in Washington and California, but not in Oregon, is the result of a greater amount of sand influence in Oregon.

\section{CONCLUSIONS}

Further long term studies are needed to document year-to-year variation in sand coverage, and the potential importance of such variation to patterns of distribution and abundance of organisms in these habitats. Littler et al. (1983) suggest that only 2 types of plants can survive on sand-stressed shores: (1) stress tolerant plants, and (2) rapidly invading ephemeral plants. The relative abundance of these 2 groups may vary with the depth, duration and intensity of sand stress. According to their classification scheme, Rhodomela larix would be a stress tolerant plant, tolerating both burial and scour. However, $R$. larix plants themselves may succumb to sand exposure if depth and duration of sand coverage or scour is too great. Clearing experiments are presently underway to determine the pattern of colonization of cleared areas in sandy habitats. Preliminary observations suggest that $R$. larix regains dominance in clearings where it was peviously present by vegetative proliferation and perennation from basal cells left during the clearing process. Hence, $R$, larix monocultures, once established, may be maintained because of the growth characteristics of the plant and its relative tolerance to environmental hardships such as sand. In addition the ability of $R$. larix itself to trap sediment may inhibit recruitment of other species of plants and animals around it and should be investigated.

Acknowledgements. This study was completed as a portion of my master's thesis research at Oregon State University. I am grateful to my former advisor Dr. Jane Lubchenco for her support and encouragement throughout the study, and to an NSF grant to Drs. B. Menge and J. Lubchenco for partial funding. This study profited greatly from discussions with Tom Dudley who also provided field assistance. Teresa Turner, B. Menge, P. Dawson, C. Marsh and 2 anonymous reviewers provided useful comments on an earlier draft and Terry Hughes provided assistance with the digitization for Table 6.

\section{LITERATURE CITED}

Abbott, I. A., Hollenberg, G. J. (1976). Marine algae of California. Stanford Univ. Press, Palo Alto, California

Chapman, V. J. (1946). Marine algal ecology. Bot. Rev. 12: $628-672$

Connell, J. (1970). A predator-prey system in the marine intertidal region. I. Balanus glandula and several species of predatory species of Thais. Ecol. Monogr. 40: 49-78

Connell, J. (1975). Some mechanisms producing structure in natural communities: a model and evidence from field experiments. In: Cody, M. L., Diamond, J. M. (ed.). Ecology and evolution of communities. Belknap Press, Cambridge, Massachusetts, p. 460-490

Connell, J. (1978). Diversity in tropical rainforests and coral reefs. Science 199: 1302-1310

Daly, M. A., Mathieson, A. C. (1977). The effects of sand movement on intertidal seaweeds and selected invertebrates at Bound Rock, New Hampshire, USA. Mar. Biol. 43: $45-55$

D'Antonio, C. M. (1982). Population ecology of the red alga, Rhodomela larix (Turner) C. Agardh, on the central Oregon coast. Master's thesis, Oregon State Univ., Corvallis

D Antonio, C. M. (1985). Epiphytes on the rocky intertidal red alga, Rhodomela larix (Rhodophyta, Ceramiales): negative effects on the host and food for herbivores. J. exp. mar. Biol. Ecol. 26: 197-218

Dayton, P. K. (1971). Competition, disturbance and community organization: the provision and subsequent utilization of space in a rocky intertidal community. Ecol. Monogr. 41: 351-389

Dayton, P. K. (1975). Experimental evaluation of ecological dominance in a rocky intertidal community. Ecol. Monogr. 45: $137-159$

Dethier, M. N. (1982). Pattern and process in tidepool algae: factors influencing seasonality and distribution. Botanica Mar. 25: 55-66

Dethier, M. N., Duggins, D. O. (1984). An 'indirect commensalism' between marine herbivores and the importance of competitive hierarchies. A.m. Nat. 124: 205-219

Doty, M. S. (1947). The marine algae of Oregon. Farlowia 3: $1-65,159-215$

Gaines, S. P. (1985). Herbivory and between habitat diversity: the differential effectiveness of defenses in a marine plant. Ecology 66: 473-485 
Grime, J. P. (1977). Evidence for the existence of 3 primary strategies in plants and its relevance to ecological and evolutionary theory. Am. Nat. 111: 1169-1194

Hartlett, J. D. (1972). Sediment transport on the northern Oregon continental shelf. Ph. D. thesis. Oregon State Univ., Corvallis

Highsmith, R., Riggs, A., D'Antonio, C. (1980). The survival of hurricane generated coral fragments and a disturbance model for reef calcification/growth rates. Oecologia (Berl.) 46: $322-329$

Komar, P. (1976). Beach processes and sedimentation. Prentice Hall, Englewood Cliffs, New Jersey

Levin, S., Paine, R. T (1974). Disturbance, patch formation, and community structure. Proc. Natn Acad. Sci. U.S.A. 71 $2744-2747$

Littler, M. M., Martz, D. R., Littler, D. S. (1983). Effects of recurrent sand deposition on rocky intertidal organisms: importance of substrate heterogeneity in a fluctuating environment. Mar. Ecol. Prog. Ser. 11: 129-139

Markham, J. W. (1973). Observations on the ecology of Laminaria sinclairii on three northern Oregon beaches. $\mathrm{J}$ Phycol. 9: 336-341

Markham, J. W., Newroth, P. R. (1972). Observations on the ecology of Gymnogongrus linearis and related species. Intl. Seaweed Sym. 7: 127-130

Mathieson, A. C. (1965). Contributions to the life history and ecology of the marine brown alga, Phaeostrophion irregulare Ph. D. dissertation, Univ. of British Columbia, Vancouver

Muenscher, W. L. (1915). A study of the algal associations of San Juan Island. Puget Sound Biol. Stat. Publ. 1: 59-83

Paine, R. T. (1966). Food web complexity: species diversity. Am. Nat. 100: 65-75

Paine, R. T. (1977). Controlled manipulations in the marine intertidal zone, and their contributions to ecological theory. The changing scenes in the natural sciences. Spec. publ. Academy of Nat. Sciences, Philadelphia 12: 245-270

Paine, R. T (1984). Ecological determinism in the competition for space. Ecology 65: 1339-1348

Paine, R. T., Levin, S. (1981). Intertidal landscapes: disurbance and the dynamics of pattern. Ecol. Monogr. 51: $145-178$

Paine, R. T., Vadas, R. (1969). The effects of grazing by sea urchins, Strongylocentrotus spp., on benthic algal populations. Limnol. Oceanogr. 14: 710-719
Phinney, H. K. (1977). The macrophytic marine algae of Oregon. In: Krauss, R. W. (ed.) The marine plant biomass of the pacific Northwest Coast. Oregon State Univ. Press, Corvallis, p. 93-116

Robles, C. (1982). Disturbance and predation in an assemblage of herbivorous diptera and algae on rocky shores Oecologia (Berl.) 54: 23-31

Runge, E. J. (1966). Continental shelf sediments, Columbia River to Cape Blanco, Oregon. Ph. D. dissertation, Oregon State Univ., Corvallis

Saito, Y (1980). Suitable habitats for certain algae with respect to their growth on the vertical surface of breakwaters. Jap. J. Phycol. 28 (3): 171-176

Sousa, W. (1979a). Experimental investigations of disturbance and ecological succession in a rocky intertidal algal community. Ecol. Monogr. 49: 227-254

Sousa, W (1979b). Disturbance in marine intertidal boulder fields: the nonequilibrium maintenance of species diversity. Ecology 60: 1225-1239

Sousa, W (1984). Intertidal mosaics: patch size, propagule availability, and spatially variable patterns of succession. Ecology 65: 1918-1935

Sousa, W., Schroder, S., Gaines, S. (1981). Latitudinal variation in intertidal algal community structure: the influence of grazing and vegetative propagation Oecologia (Berl.) 48: $297-307$

Stephenson, T A., Stephenson, A. (1972). Life between tidemarks on rocky shores. W H. Freeman and Co., San Francisco

Stewart, J. G. (1983). Fluctuations in the quantity of sediments trapped among algal thalli on intertidal rock platforms in southern California. J. exp. mar Biol. Ecol. 73: 205-211

Sutherland, J. (1974). Multiple stable points in natural communities. Am. Nat. 108: 859-873

Sutherland, J. P. (1981). The fouling community at Beauford, North Carolina: a study in stability. Am. Nat. 118: 488-498

Taylor, P. R., Littler, M. M. (1982). The roles of compensatory mortality, physical disturbance, and substrate retention in the development and organization of a sand-influenced, rocky-intertidal community. Ecology 63: 135-146

Thurmen, H. V. (1975). Introductory oceanography. Merrill Publ. Co., Columbus, Ohio

Turner, T (1982). Community organization and succession in rocky intertidal surfgrass beds. Ph. D. dissertation, Oregon State Univ., Corvallis

This paper was presented by Professor J. S. Pearse; it was accepted for printing on September 18, 1985 